new village-designed grain stores were built and in use, several other improved stores were built, even the poorest were using insecticide, the village storage committee had set up a research project to monitor results, the village had agreed to teach 15 other villages to analyse their storage problems, and the committee held a seminar at the university. "It was at this point, recounts the Report on the project, that the committee members really began to see themselves as storage experts".

These Tanzanians had begun not only a process of improving their storage practice but also a process of using their own and outside technology for their own benefit.

Outside technology however cannot usually be applied directly; its principles and techniques may be valid worldwide, but their use varies as much as the people who use them. When technology is transferred from one society to another, the principles and techniques remain the same, but they are re-arranged and combined with a different set of social and economic activities-to make a technology that has been "transformed".

In order to "transform" a technology, people need a range of possibilities from which they can select and test those most relevant to their needs, combine them with elements from their own technology, and work out the new social and economic arrangements needed.

The new technology may mean more time for women, or more work for women; more money for everyone, or more money for one or two people; less free time in the festival season, too much work in the peak weeding season; community work to empty latrines, community contributions to pay for a maintenance worker. It may mean new institutions at family level, as when a new agricultural technique tends to transfer work from women to their husbands; at village level, as when village meetings have to choose somebody to go for training as a village health worker; or at local government level, as when the technicians are needed to maintain village pumps, cover a whole district and have to be organised from a central office.

Outsiders (such as people in Britain) can develop appropriate technologytechniques or hardware which perform needed tasks. But only the people who are to use the technology can transform it; only they can adapt their ideas (on the role of women for instance, or the importance of festivals) and their social and economic arrangements.

How then can Britain help the very poor to develop their own technology and transform outside technology? The answer lies in a new sort of programme - a programme whose leading edge is in the slums and villages of the Third World where the poorest are. Field staff, many of them local, would seek out, stimulate and finance projects such as the Tanzanian grain-storage one described earlier, helping it to grow into a countrywide system, including (if need be) training for extensionists and laboratory and workshop facilities.
The field staff would have access to funds not tied to British salaries or equipment, and the programme would be able to finance non-government bodies in the Third World. There are various ways such a programme could be organised-as a development of one of the Ministry of Overseas Development's existing units, as a new Council for the Use of Technology Overseas (or something), or as a non-government body (perhaps a multilateral one).

A programme of this kind would be quite a change from Britain's present aid for science and technology. The basic premise in Britain is that they have the problems, we have the solutions. Technology made us rich; we have only to apply it to make them rich. The tradition in Britain is to do things for the poor in the Third World -a kind of charity even when run by the government.

But it is not much help to make people the passive recipients of a technology designed elsewhere; there needs to be a close connection between the development of a technology and the society in which it is to be used. We should be concerned not so much with the appropriateness of a particular piece of technology, as with the appropriateness of the process of technical change. That is what the new programme would be about.

This article is based on Good servant, bad master by Adrian Moyes, published on 8 March, available from Oxfam Publications, 274 Banbury Road, Oxford, UK, price $f I$ post free.

\title{
Stockholm institute supports Third World scientists
}

DR I. M. Nitis, at the Udayana University of Denpasar in Bali, is working on stylosanthes as a companion crop to cassava. He has discovered that the extra green feed produced by the combination of the two crops could support one or two yearling Bali cattle per hectare for a year. His work has been financed by three grants, ranging from $\$ 555$ to $\$ 6,600$, from the International Foundation for Science (IFS). "The IFS only gives a little money, but it leaves me to work quite independently", he says. "The beauty of the foundation is that it helps young thirdworld scientists just starting their own research. If their project is successful, a bigger organisation-the UN Food and Agriculture Organisation, for example-will pick them up." Dr Nitis is one of 250 young scientists in 44 developing countries receiving support.

"Our grants have been limited to research in applied biology and agriculture--work which could be carried out in the villages", explained Professor Sven Brohult, founder and President of IFS. "We want to establish self-

\section{Wendy Barnaby reports on the work of the International Foundation for Science}

supporting units on the farms and in the villages. It's like the old Chinese experiment of having everyone selfsupporting on a small scale so that nobody actually starves. We must avoid contributing to urbanisation and bureaucracy. We leave big investments to the big organisations. Our idea is to encourage indigenous, simple technology."

So far, grants have been given under six categories: aquaculture; animal production; vegetables, oil seeds and fruits; afforestation problems; fermentation and methods for food preparation; and natural products. "We feel the work has been rather successful in these fields", added Professor Brohult, "and are thinking of going into another: rural construction. On a very simple level, of course. How to construct a fishpond, for example: you have to have a certain slope around the walls.
And we could help in supplying energy to rural communities. Using simple means to dry fish with solar energy."

To qualify for a grant, a project must be relevant to the needs of a developing country and the researchers must be native to, and carry out their work in, a developing country, where their salaries are paid by the institute that normally employs them. All applications are adjudicated by voluntary scientific advisers.

This sort of volunteer work is gratefully received: IFS's total budget last year was just under $\$ 1$ million. The money came as government grants from nine countries: Sweden, Canada, France, the Federal Republic of Germany, Belgium, Norway, the Netherlands. Nigeria and Switzerland.

Although the day-to-day running of IFS is left to its small, Stockholm-based staff, guidance and ideas are provided by about 50 member organisations: arademies of science around the world. The most recent to join, to Professor Brohult's great delight, is the Royal Society in London. 